\title{
On the Comparative Anatomy of the Genera Ceraria and Portulacaria. ${ }^{1}$
}

\author{
BY
}

\author{
MARGARET RUTHERFORD MICHELL, B.A., \\ Queen Victoria Scholar of the University of the Cape of Good Hope.
}

With Plate XCVIII and four Figures in the Text.

$\mathrm{T}$ HE three species of the genus Ceraria are all typical xerophytes, well adapted to the dry situations in which the plants grow. The material for this investigation was obtained by Dr. Pearson in South-West Africa. As both species were found during the flowering season, which does not coincide with the period of greatest vegetative activity, some interesting points connected with the structure of the stem could not be determined with certainty. Ceraria gariepina was found on granite hills in Bushmanland, on the same slopes as Pachypodium namaquanum, in January, I9o9 (Text-fig. I).

Ceraria namaquensis, material of which was obtained in the Richtersveld in January, I9II, had previously been found by Atherston and Wyley in undefined localities in Namaqualand. ${ }^{2}$ Both these species are small trees, averaging about twelve feet in height. Until recently $C$. namaquensis was known as Portulacaria namaquensis, under which name it appears in the 'Flora Capensis'.3 It has now, on account of important characters of ovary and fruit, been placed in a separate genus, Ceraria, ${ }^{4}$ of which two other species are known, C.gariepina and $C$.fruticulosa. Portulacaria afra, now the only species in the genus, is a large shrub common in the Karroo.

On account of the close systematic relationship between the two genera it was thought that a comparative study of the anatomy might prove interesting. The stem of Ceraria is covered with thick leathery bark, interrupted at regular intervals by the prominent nodes, each of which bears several minute sessile leaves. The plants were only seen during the flowering period, when the number of leaves was small. At other seasons the leaves are probably more numerous. They are extremely small (2-4 mm. in length), obovoid in shape, and extremely fleshy. The branching

1 Percy Sladen Memorial Expedition in South-West Africa. Report No. 1\%.

2 Pearson ('11), p. I9I (2).

3 Sonder, pp. $3^{8} 5^{-6}(7)$.

4 Pearson and Stephens ('12) (3).

[Annals of Botany, Vol. XXVI. No. CrV. October, 1912.] 
in this genus is pseudo-dichotomous, ${ }^{1}$ therein differing from that in Portulacaria, where the branching is of the ordinary lateral type.

Solereder gives a brief account of the anatomical features of the Portulaceae, ${ }^{2}$ but little work appears to have been done with regard to this order. Mention is made of a few of the outstanding characters of Portulacaria afra. None of the features of this order, upon which Solereder lays stress, is absent in Ceraria, although in a few minor details this genus seems

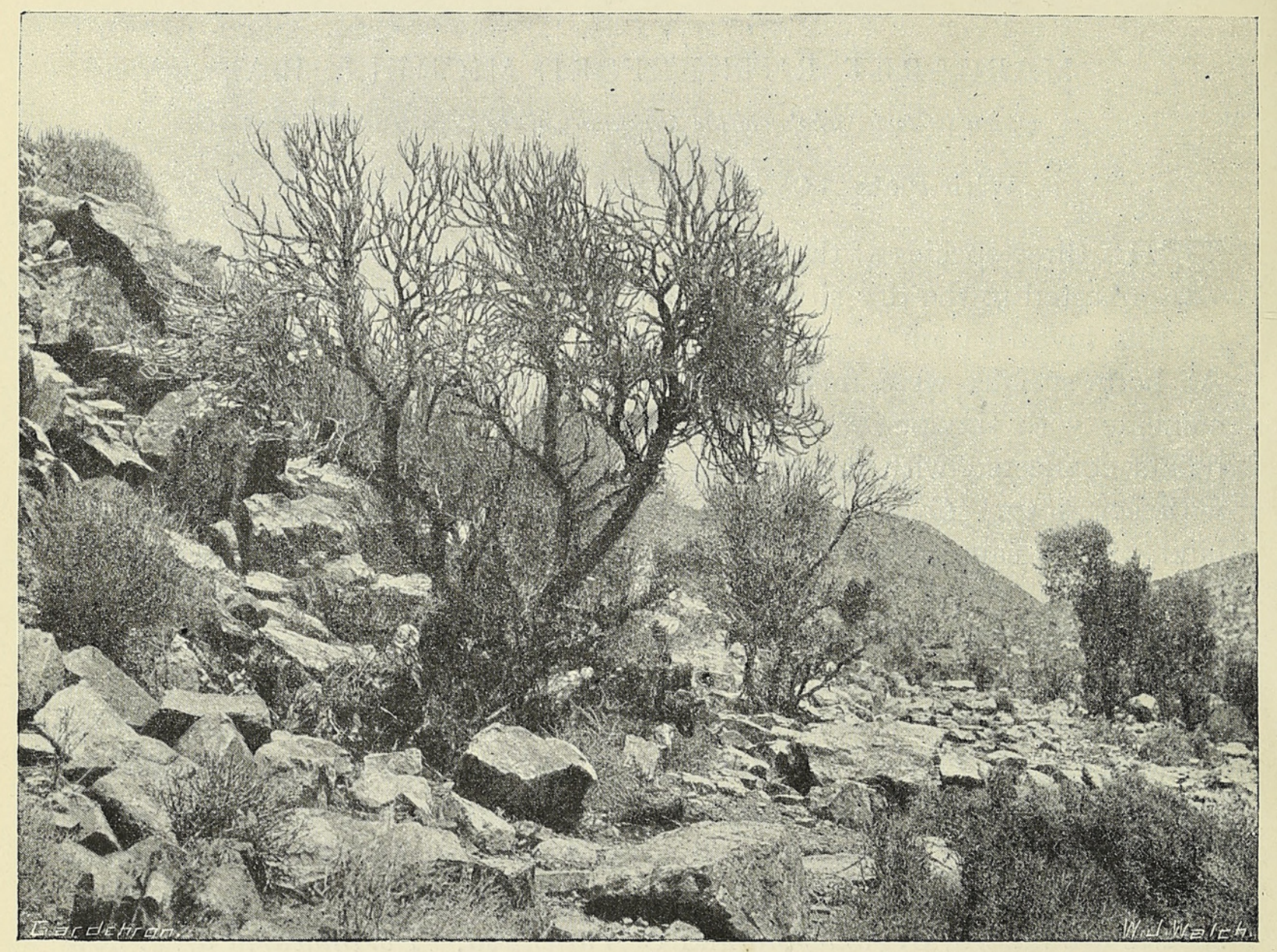

Text-Fig. I. Ceraria gariepina. Photograph taken at Aggenys in Bushmanland in 1909 by Dr. H. H. W. Pearson. From the 'Gardeners' Chronicle'.

to have no parallel in the other genera. The arrangement of the mucilage cells, and the occurrence of calcium oxalate in the intercellular space beneath a stoma, may be quoted as instances of this.

\section{Anatomý.}

\section{C. namaquensis.}

\section{A. Leaf.}

The structure of the leaf corresponds very closely with that of Portulacaria afra, to which genus Ceraria is closely allied. Proceeding from without inwards, it is found that the epidermis has its outer and inner walls cutinized to a very great extent (Pl. XCVIII, Fig. I). The radial walls are

1 Pearson and Stephens ('12) (3).

2 Solereder ('08), vol. i, pp. I I I-I 3 (6). 
only to be seen with difficulty, and with a low-power objective the outer and inner walls alone are visible. The guard cells (P1. XCVIII, Fig. 2) are spherical in section, and are accompanied by two subsidiary cells (Pl. XCVIII, Fig. 3) placed parallel to the pore. A peculiar feature of the leaf is the occurrence of calcium oxalate crystals in the intercellular space beneath several of the stomata.

De Bary ${ }^{1}$ and Sachs ${ }^{2}$ both cite a few cases in which calcium oxalate is present in the cell-walls of the epidermis, though the formation of crystals of this substance in intercellular spaces is unrecorded by them. According to Sachs the occurrence of calcium oxalate in the cell-walls is rare among Angiosperms, only having been observed by Solms-Laubach in certain species of Mesembryanthemum and in Sempervivum calcareum. Pfeffer has recorded the occurrence of these crystals in the cell-walls of some Dracaenas, and in these cases calcium oxalate is not confined to the epidermis, but is found also in cells lying deeper in the tissue. On the authority of SolmsLaubach it is stated that these crystals occur commonly in the Gymnosperms, being formed in the middle lamellae of the cell-walls. No indication of a similar origin of the crystals in Ceraria is given. No definite palisade tissue occurs, the outer cells of the mesophyll containing numerous chloroplasts. These decrease in number as the centre of the leaf is approached, though none of the central cells is devoid of them. Below the epidermis, large brown mucilage cells are found in which there are no chloroplasts. In this species the mucilage cells occur scattered in the first two rows of cells beneath the epidermis. The vascular bundles are small in section and vary but little in size. There are from seven to eleven bundles in a leaf, and these are deeply embedded in the tissues, so being invisible from the outside. The appearance in transverse section is that of a parallel-veined leaf, but it can be shown by cutting a section in the plane of venation that the bundles form a loose reticulum. Each bundle leaves the primary vein at a small angle, and almost immediately assumes a direction parallel to that of the central bundle. At the tip all the bundles branch and anastomose, so giving rise to a complex network.

Clustered crystals of calcium oxalate occur in the mesophyll. There are two kinds of these crystals. The first has a rough sandy appearance, due to the fact that all the crystals in a cluster are not of the same length and some project beyond the others, so giving the whole mass, when highly magnified, a spiny appearance. These crystals resist the action of nitric acid longer than the large crystals which are found beneath some of the stomata. This second kind of cluster is made up of a large number of slender wedge-shaped crystals, radiating from a centre and so forming a hemispherical mass. 


\section{C. gariepina.}

This species resembles the former in all its outstanding features. The following differences, however, must be noted:

(a) The mucilage cells are less numerous, and only occur in the cell row immediately below the epidermis.

(b) The crystals of calcium oxalate are more numerous, and the larger clusters occur in the cells of the mesophyll as well as below stomata. Crystal-blocked stomata are more frequently found in this species, about 20 per cent. of the stomata possessing the crystals.

The leaf of Ceraria affords a good example of the xerophytic structure so common in plants growing in dry regions. The size and shape of the leaf are to be noticed in this connexion. In Ceraria the xerophytism is more pronounced than in the allied genus Portulacaria, and the differences which exist between the leaves of the two genera are correlated with this fact.

\section{B. Stem.}

\section{C. gariepina.}

The most striking feature in a transverse section is the broad band of dark-brown mucilage cells occurring in the cortex. This ring does not appear to be found in the other genera of this order. ${ }^{1}$ The stem is surrounded with a thick bark, an account of which is given below.

Cortex. In the cortex there are three distinct bands of tissue (Fig. 4). Next the bark are large water-storing cells, separated from one another by radial bands of parenchyma. The mucilage band occupies the greater part of the cortex, and consists of large mucilage-containing cells interrupted here and there by small parenchyma cells. The innermost layer of the cortex consists of ordinary ground tissue with groups of sclerenchymatous cells immediately opposite the bundles.

Endodermis. The endodermis is not marked.

Stele. The vascular bundles are arranged in a ring, and are very similar to those of Portulacaria afra, the chief difference in the vascular cylinder being that in Ceraria three or four of the medullary rays are broader than the rest. There are about twenty open bundles of the usual collateral type, and in the oldest stem available three faintly marked annual rings could be distinguished (Fig. 6).

Phloem. The phloem is characterized by a great development of fibres on the outer side of each phloem mass. All elements of the phloem have an extremely small transverse diameter, and for this reason the separate elements are difficult to identify. The sieve plates occur on both the lateral and the end walls of the sieve-tubes, but owing to their small size, and the difficulty experienced in obtaining microtome sections, their

\footnotetext{
1 Solereder ('08), p. II 2 (6).
} 
structure could not be determined (P1. XCVIII, Fig. 5). A small amount of parenchyma occurs in the phloem, but companion cells have not been recognized with certainty.

Cambium. The xylem is separated from the phloem by a definite cambium, usually two or three cells wide.

Xylem. The most striking feature of the xylem is the entire absence of bordered pits, ${ }^{1}$ simple pits being found in the vessels, tracheides, parenchyma, and fibres. The pits are often horizontally elongated, though

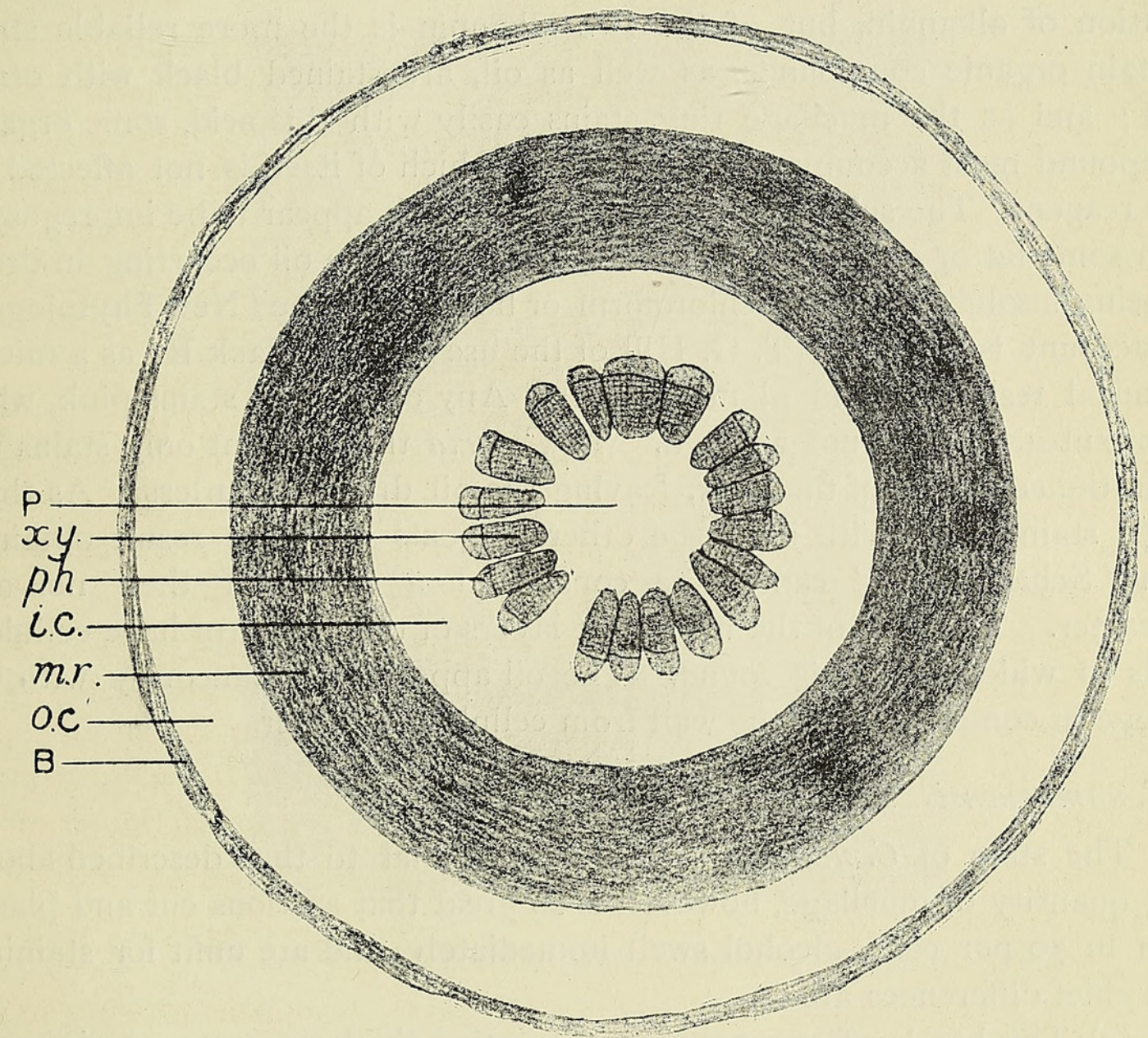

TeXT-FIG. 2. Ceraria namaquensis. Diagrammatic representation of a transverse section through the stem. $\mathrm{P}=$ pith $; i . c_{.}=$inner cortex $; m . r .=$ mucilage ring $; 0 . c .=$ outer cortex $; b=$ bark. $\times \mathbf{1} 6$.

not enough so to justify the use of the term scalariform. Lignified parenchyma cells are present, but not to any great extent. Fibres are abundant as in the phloem, differing, however, in this case in being slightly pitted. The pits are more numerous on the walls adjoining the other xylem elements than elsewhere. Spiral tracheides, constituting the protoxylem, show no peculiarities.

Pith. The pith is small in amount, and consists entirely of parenchyma. 
Clustered crystals of calcium oxalate are found in great abundance. In the large water-storing cells beneath the periderm, clusters occur which may extend over two or three cells. These clusters are larger, but otherwise resemble the second type described in the leaf (P1. XCVIII, Fig. 7). Clusters of the first type are abundant in the parenchyma of the stem.

No starch is found in this species, probably owing to the fact that the material was obtained during the early part of the vegetative season.

Throughout the stem, drops of some fixed oil occur. These stain easily with either a I per cent. solution of osmic acid or an alcoholic solution of alkannin, but of the two alkannin is the more reliable stain. Certain organic compounds, as well as oil, are stained black with osmic acid; and as the mucilage ring stains easily with this acid, some organic compound must accompany the mucilage, which of itself is not affected by this reagent. The suberized cell-walls of the bark appear to be impregnated with some fat or oil, which, however, differs from the oil occurring in drops in being insoluble in ether, chloroform, or benzol. In the 'New Phytologist' an account is given by T. G. Hill of the use of 'Scharlack R' as a microchemical test for oil in plant tissues. ${ }^{1}$ Any oil present stains pink, while other substances are not affected. In Ceraria this reagent only stains the oil in the cell-walls of the bark, leaving the oil drops colourless. As these drops stain easily with both the other reagents used, the result obtained with 'Scharlack $\mathrm{R}$ ' cannot be considered a proof of their non-oily character. The cells of the innermost layers of the periderm have cellulose walls in which no oil is found. The oil appears simultaneously with the change in composition of the wall from cellulose to suber.

\section{C. namaquensis.}

The stem of $C$. namaquensis is very similar to that described above. The quantity of mucilage, however, is so great that sections cut and placed even in 70 per cent. alcohol swell immediately, and are unfit for staining. The chief differences are:

(a) The bands of parenchyma separating the large water-storing cells are in this case extremely narrow.

(b) Annual rings are absent, which fact, however, is not remarkable, as there are two rainy seasons a year in the regions in which this plant grows.

(c) The material of this latter species was gathered at the end of the principal vegetative season, and therefore it is not surprising that large quantities of starch are found in the parenchyma throughout the stem.

(d) The oil which is present in C. gariepina is found here as well, the only difference being that the quantity is considerably less. The suberized cells of the bark do not stain as deeply with alkannin in this species as they do in C. gariepina.

$$
{ }^{1} \text { Hill ('12), (10). }
$$




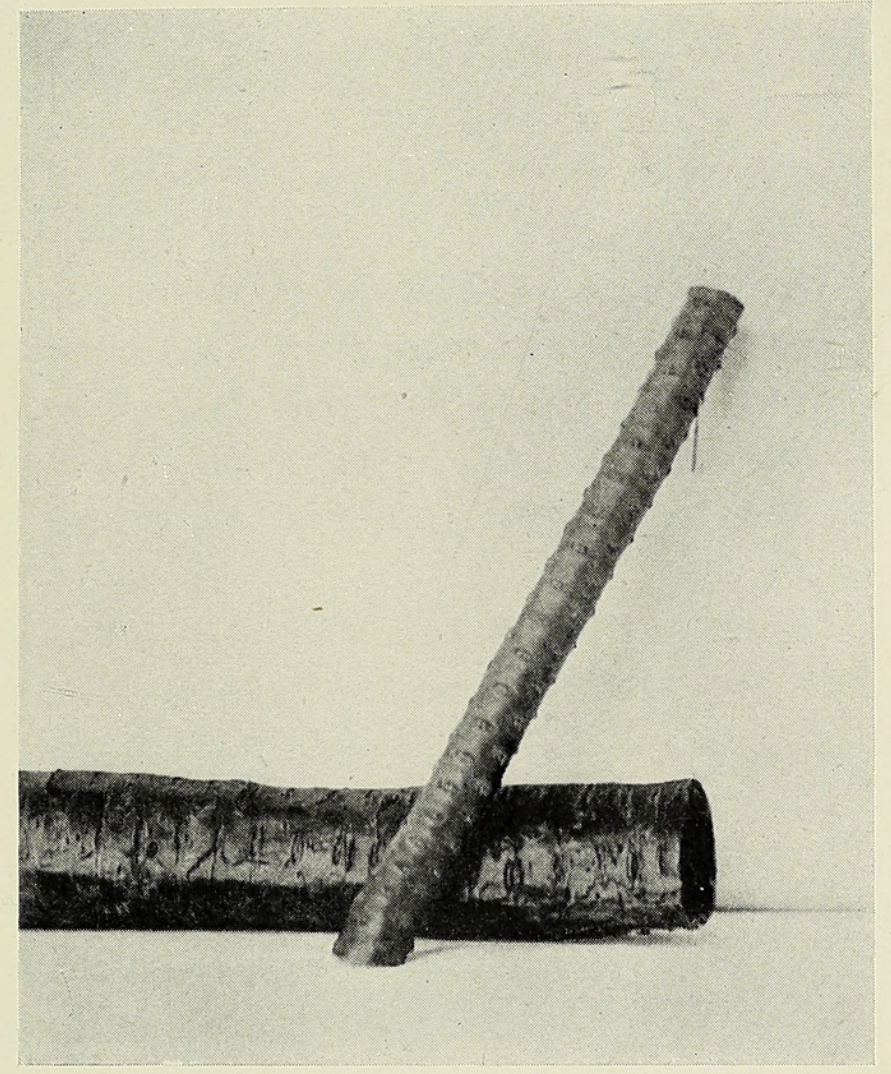

TeXT-FIG. 3. Bark of Ceraria gariepina. Photographed by J. A. Michell. 

From what has been said it would appear that two distinct kinds of oil are found in the stem:

I. The drops of oil occurring throughout the stem in the cell cavities.

2. The oil permeating the corky walls of the bark.

It is possible that the oil-drops have been converted from starch into oil during the resting period, and that these plants are of the same nature as those designated by A. F. W. Schimper 'fat trees'.' The fact that no starch but much oil is found in C. gariepina which was gathered during the resting period, and that $C$.namaquensis which was obtained at the beginning of the resting period has a large quantity of starch and little oil, tends to support this hypothesis.

\section{Periderm.}

An interesting feature of Ceraria is the great development of leathery bark. This can easily be separated from the rest of the stem, and thus hollow cylinders of bark may be obtained in an unbroken condition (Text-fig. 3 ).

In the bark of $C$. gariepina there is some inflammable substance which does not appear to be present in as large quantities in $C$. namaquensis, and which causes the living plant to burn easily. The results of a chemical investigation of the constituents of the bark are not yet available. This phenomenon suggests a comparison with Dictammus albus, the Candle-plant, ${ }^{2}$ which secretes an extremely volatile oil. On calm hot days, if a match be applied the surrounding air takes fire and the plant itself burns.

In Ceraria namaquensis the apex of the stem is protected by a number of scale leaves, the base of which consists of mucilage cells similar to those of the stem (Pl. XCVIII, Fig. 8). Immediately behind the scale leaves the epidermal cells appear to give rise to a cambium which persists throughout the life of the plants, cutting off cells on its outer side only. It cannot be stated with certainty that this is a cambium, although it seems probable. Only in three or four cases have cells been seen to have divided recently, but considering that the material was gathered at the end of the vegetative season, it would appear that the cambium had entered upon a period of rest. Support is lent to this supposition by an examination of two lots of material of Portulacaria afra obtained in the Cape Peninsula. Material (A) was collected in June at the commencement of vegetative activities, and this shows that a large number of cells of the phellogen had recently divided. Material (B) was gathered in January, during the resting period, and in this only two or three cells of the cambium had recently divided. There is no phelloderm formed and the number of cell rows separating the cambium from the large water-storing cells of the cortex is constant. As a rule only one row of these cells is present. The cambium first of all cuts

$$
1 \text { Schimper ('03), pp. 436-7. }
$$$$
2 \text { Willis ('04), p. } 35^{\circ} \text { (9). }
$$ 
off tubular thin-walled cork cells, and continues doing so until from fourteen to eighteen rows of cells have been formed. The cells which are now cut off have not the definite rectangular outline which characterizes the first type (Pl. XCVIII, Fig. 9) of cell formed, and they possess slightly thickened cellulose walls (Pl. XCVIII, Fig. Io). These cells become more and more crushed and stretched as new cells are cut off from the cambium. It is not, however, till their outline is hardly recognizable that they become suberized.

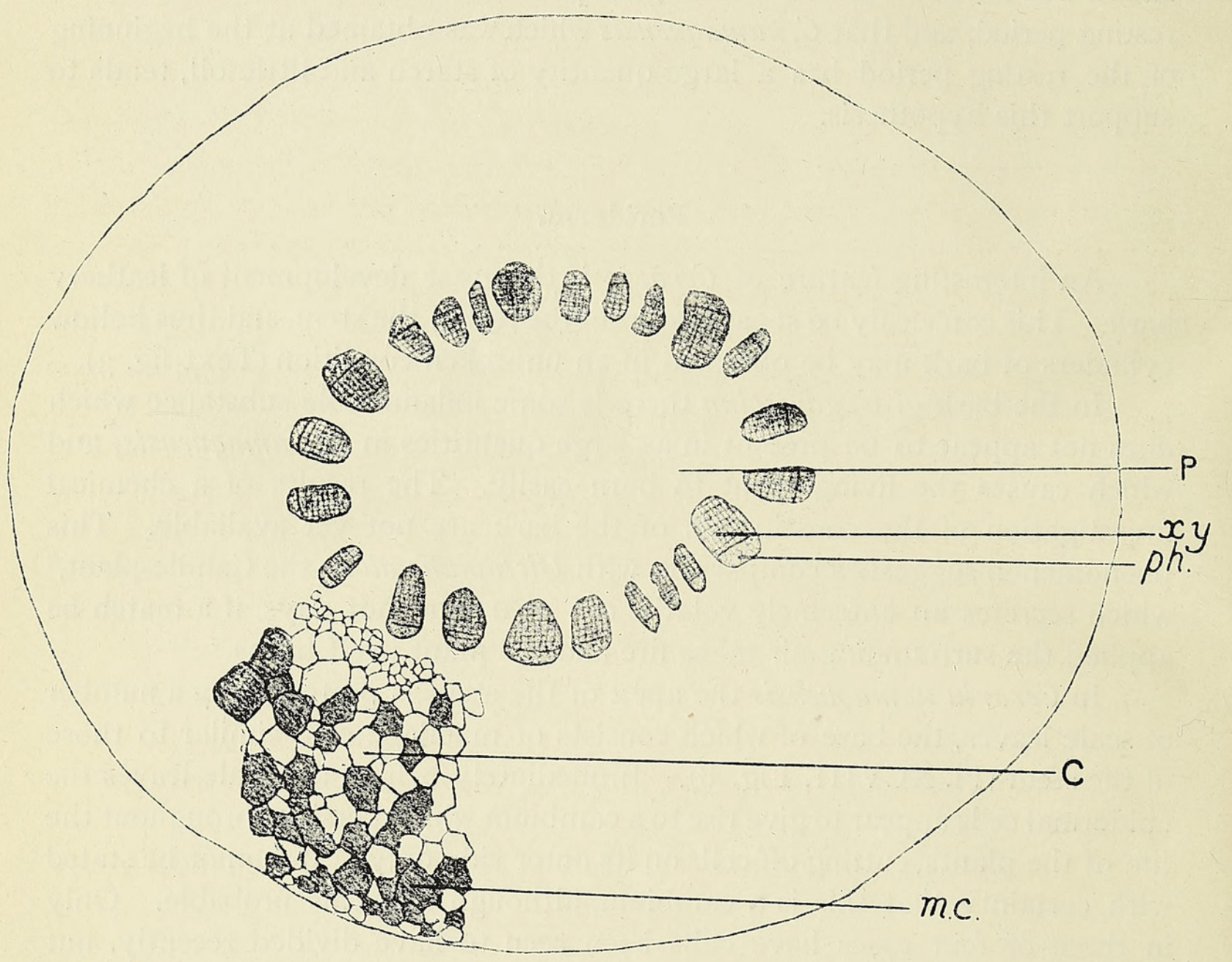

TeXt-Fig. 4. Portulacaria afra. Diagrammatic representation of a section through the stem. $\mathrm{P}=$ pith $; x y .=$ xylem $;$ ph. $=$ phloem $; \mathrm{C}=$ cortex $;$ m.c. $=$ mucilage cells. $\times \mathrm{I} 6$.

In the older parts of the stem it is these cork cells which constitute the bark, the first formed cork having worn away. In this no cell outlines are visible, and the lamellated appearance in section is due to the tangential walls of the original cells remaining distinct, while only traces of the radial walls are left. In $C$. gariepina the cork consists of a number of layers easily separated from one another, and in the young stem every alternate layer stains with safranin. Later on the cork stains uniformly, but the layers still remain distinct (P1. XCVIII, Fig. II). Possibly each of these layers represents the total amount of growth in one year. The fact that in 
C. namaquensis, where the xylem shows no annual rings, the cork is not as distinctly layered as in $C$.gariepina favours this supposition.

It is quite probable that when suitable material is obtainable, phelloderm may be found to be present, and in that case the position assigned to the cambium will be incorrect.

Material for examining the apex of the stem of $C$. gariepina was not available, but as the formation of bark on the lower parts of the stem in this species is identical with that in $C$.namaquensis it is not probable that any differences of a serious nature are to be anticipated.

In Portulacaria afra the bark is less strongly developed, but in the older stems it shows the same structure as in Ceraria. The phellogen arises in the epidermis (Pl. XCVIII, Fig. I2) and cuts off cells on the outside only, as in Ceraria. These cork cells are thin-walled but are not rectangular in outline, and become crushed almost as soon as they are formed. No band of cellulose cells separates the cambium from the cork (Pl. XCVIII, Fig. I3). In Portulacaria afra, therefore, only one type of cork cell is found, while in Ceraria there are two. The stem apex is protected by two young foliage leaves and not by scale leaves as in Ceraria.

The anatomy of the stem agrees very closely with that of Portulacaria afra (Text-fig. 4). The points in which these two genera differ may be tabulated as follows:

CERARIA. PORTULACARIA.

\section{$L E A F$.}

I. Leaf club-shaped.

2. Cuticle very marked.

3. Palisade tissue slightly differentiated.

4. Crystals beneath the stomata.
I. Leaf flat and obovoid.

2. Cuticle not conspicuous.

3. Tissues not differentiated.

4. Nocrystals beneath the stomata.

\section{STEM.} ture.

I. Thick bark of a peculiar struc-

2. Large water-storing cells in cortex.

3. Mucilage cells in a ring and of a large size.

4. Four medullary rays larger than the rest.

5. Vascular cylinder occupying about one quarter of total area of stem as seen in section.

I. Bark thinner but of same structure.

2. No water-storing cells.

3. Mucilage cells forming a network in the cortex and of same size as rest of cortical cells.

4. Medullary rays all of same size.

5. Vascular cylinder occupying about one-third of total area of stem as seen in section. 
6. No tangential bands of parenchyma in the xylem.

7. Large quantities of oil present.

8. Scale leaves protecting the growing regions during the resting period.
6. Tangentialbands of parenchyma in the xylem.

7. Very few oil-drops in the cortex.

8. No scale leaves present.

\section{Nodes.}

The leaves fall off when the plant is preserved in spirit, and therefore the exact position of the leaves at each node could not be ascertained. A section through a node showed a large number of scale leaves, each consisting of mucilage cells at the base and a dark-brown suberized mass at the apex. A growing point seems to be situated at each node, and in a large number of cases in the material worked upon this has given rise to an inflorescence. In order to investigate this point thoroughly it is necessary to have materials obtained at the different seasons, and this is impossible at present owing to the long journey which must be undertaken to reach the home of these plants. The following suggestion may be made as to the changes taking place.

In the axil of each leaf a growing point arises protected by scale leaves. These fall off as soon as the need for protection ceases, and the bud gives rise to a short branch bearing a number of closely packed leaves. At the end of the vegetative season scale leaves again arise to protect the growing point, and, as before, these fall off and the short branch terminates in an inflorescence.

In $C$. namaquensis, of which stem tips were available, scale leaves exactly like those of $C$. gariepina were found on all the nodes and also surrounding the stem apex. Portulacaria afra has no scale leaves, and the foliage leaves arise in a decussate manner at the nodes. Structurally there is no great difference between Ceraria and Portulacaria, and in comparing the two plants one is struck with the resemblances rather than with the dissimilarities. From the anatomy of these plants, therefore, one is led to conclude that a close relationship exists between these two genera.

In conclusion I wish to express my thanks to Dr. H. H. W. Pearson for supplying the material, and for many helpful criticisms during this investigation.

I am also indebted to the publishers of the 'Gardeners' Chronicle' for the loan of the block from which Text-fig. I was taken.

\section{SUMMARY.}

I. In Ceraria the nodes are arranged in four longitudinal rows, many leaves being borne at each node. Portulacaria has decussate leaves.

2. Scale leaves occur in Ceraria at the nodes and at the stem apex, 
probably protecting the growing parts during the resting period. Portulacaria has no scale leaves.

3. The leaves of Ceraria and Portulacaria are very similar. They are fleshy, have no palisade tissue, and possess mucilage cells in the mesophyll.

4. Calcium oxalate is common in the stem and leaf of both genera. In the leaf of Ceraria alone, however, crystals occur in the intercellular space beneath a stoma.

5. In the stem of Portulacaria and probably of Ceraria the phellogen arises in the epidermis; apparently no phelloderm is formed.

6. A large mucilage ring occupies the middle of the cortex in Ceraria. In Portulacaria the mucilage cells form a network in the cortex.

7. In both genera the vascular bundles, which are numerous, are arranged in a ring and are separated by medullary rays. found.

8. Fibres occur in both xylem and phloem. Simple pits only are

9. Drops of oil occur in the cells of the stem of Ceraria. The cellwalls of the periderm are impregnated with some fat or oil insoluble in chloroform, ether, or benzol.

BOTANICAL LABORATORY,

South African College, April, I9I 2.

\section{LITERATURE CITED.}

1. DE BARY, A.: The Comparative Anatomy of Phanerogams and Ferns (Eng. trans.). Oxford, I 884 , p. 102 .

2. Pearson, H. H. W.: Through Little Namaqualand with the Vasculum and Camera. Gardeners' Chronicle, vol. i, Sept. 9, I9II, p. I9I.

3. - and Stephens, E. L. : Portulacaceae. Annals of the S. A. Museum, ix, I9I 2, p. 3 .

4. SAChs, J. : A Text-book of Botany. Second English edition, Oxford, I882, p. 66.

5. Schimper, A. W. F. : Plant Geography upon a Physiological Basis (Eng. trans.). Oxford, 1903.

6. Solereder, H. : Systematic Anatomy of the Dicotyledons (Eng. trans.). Vol. i, Oxford, I908, Pp. IIII-I 3 .

7. Harvey, W. H., and Sonder, O. W.: Flora Capensis. Portulacaceae. Vol. ii, I894, pp. $385^{-6}$.

8. Stevens, W. C. : Plant Anatomy. Second edition, igio, p. $3^{2} 3$.

9. Willis, J. C. : Flowering Plants and Ferns. Third edition, Cambridge, I908, p. 359.

10. Hill, T. G.: Scharlack R, a Microchemical Test for Oil. New Phytologist, vol. xi, no. 2, Feb. I9I2. 


\section{EXPLANATION OF PLATE XCVIII.}

Illustrating Miss Michell's paper on Ceraria and Portulacaria.

Fig. I. Transverse section of the leaf of $C$. namaquensis. $\quad$ ep. $=$ epidermis; $m c .=$ mucilage cells $; \mathrm{M}=$ mesophyll $; x y .=$ xylem $;$ ph. $=$ phloem. $\times 20$.

Fig. 2. Transverse section of a stoma, showing a clustered crystal of calcium oxalate in the intercellular space ; (semi-diagrammatic) C. namaquensis. g.c. $=$ guard cell ; s.c. = subsidiary cell ; $c u .=$ cuticle $; C . O . C .=$ clustered crystal of calcium oxalate; i.s. $=$ intercellular space. $\times 440$.

Fig. 3. Surface section of the leaf of C. gariepina, showing a stoma. $\times 620$.

Fig. 4. Cortex of C. gariepina. s. $=$ sclerenchyma ; i.c. $=$ inner cortex; w.S.c. $=$ water-storing cell $; c p .=$ cellulose cells of the periderm $; s_{.} p .=$ suberized cells of the periderm. $\times 100$.

Fig. 5. Longitudinal section of $C_{.}$gariepina, to show sieve-tubes. $\quad s t_{.}=$sieve-tube; $s p .=$ sieveplate on lateral wall. $\times \mathbf{I}, \mathbf{I} 00$.

Fig. 6. Transverse section of C. gariepina, to show part of two annual rings. m.r. $=$ medullary ray. $\times 440$.

Fig. 7. Water-storing cells of cortex, showing large clustered crystals of calcium oxalate in C. namaquensis. $\times 220$.

Fig. 8. Outline of stem apex of $C$. namaquensis. v.c. = vegetative cone; s.l. = scale leaf; s. $m_{\bullet}=$ suberized mass $; p_{0}=$ periderm $; p a a_{0}=$ parenchyma $; v . s_{.}=$vascular strand. $\times 33$.

Fig. 9. Longitudinal section through the outer part of the cortex of $C$.namaquensis close behind the stem apex. o.c. $=$ outer cortex; c.c. $=$ phellogen. $\times$ I I 0.

Fig. Io. Transverse section through the outer part of the cortex of C. gariepina, showing a later stage in the development of periderm. c.s.c. $=$ crushed suberized cells. $\times \mathrm{I}_{47}$.

Fig. II. Transverse section through bark of an old stem of $C$. gariepina. $\quad \times 5^{\circ}$.

Fig. I2. Transverse section of young stem of Portulacaria afra, showing origin of phellogen in the epidermis. $\times 440$.

Fig. I3. Transverse section of an older stem of $P$. afra, showing formation of periderm. $\times 440$. 
Annals of Botany,
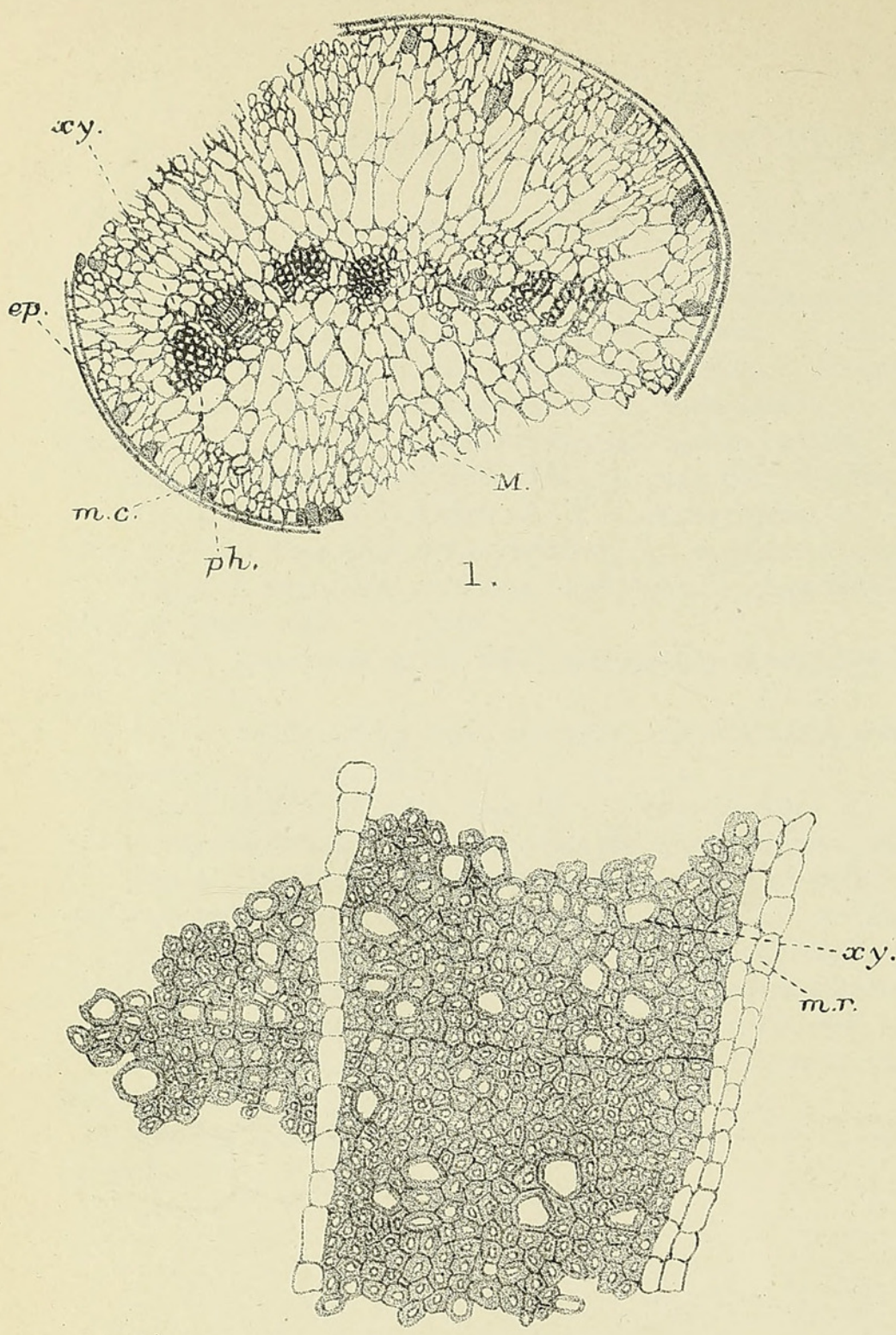

g.c.

6.

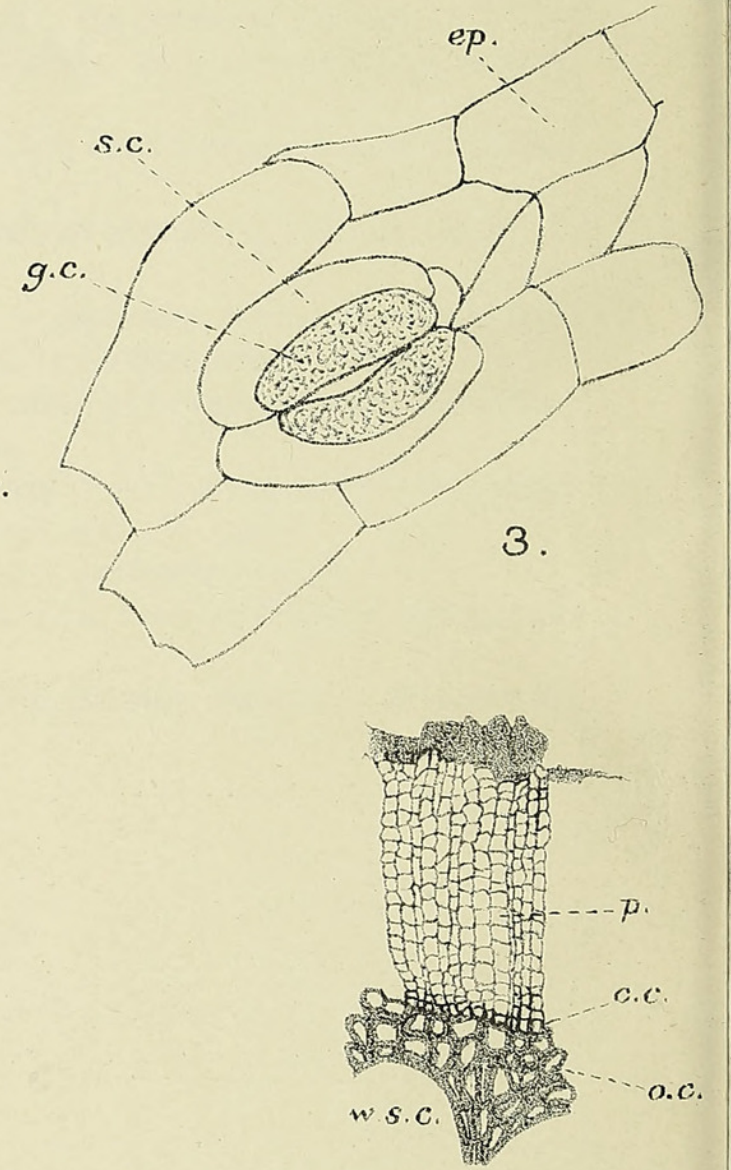

9.

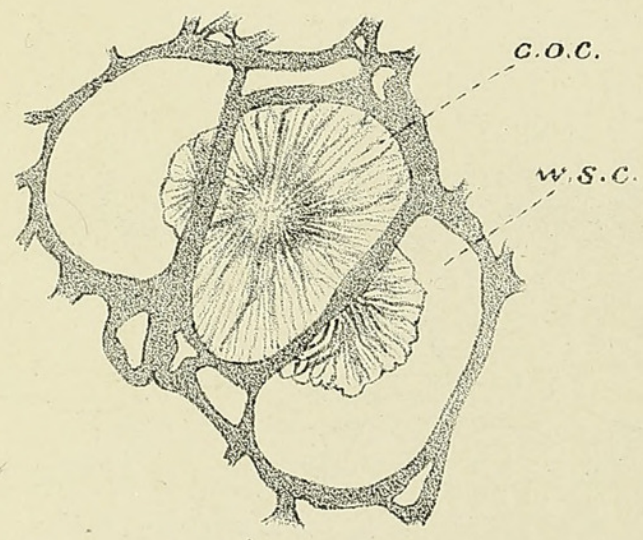

7.

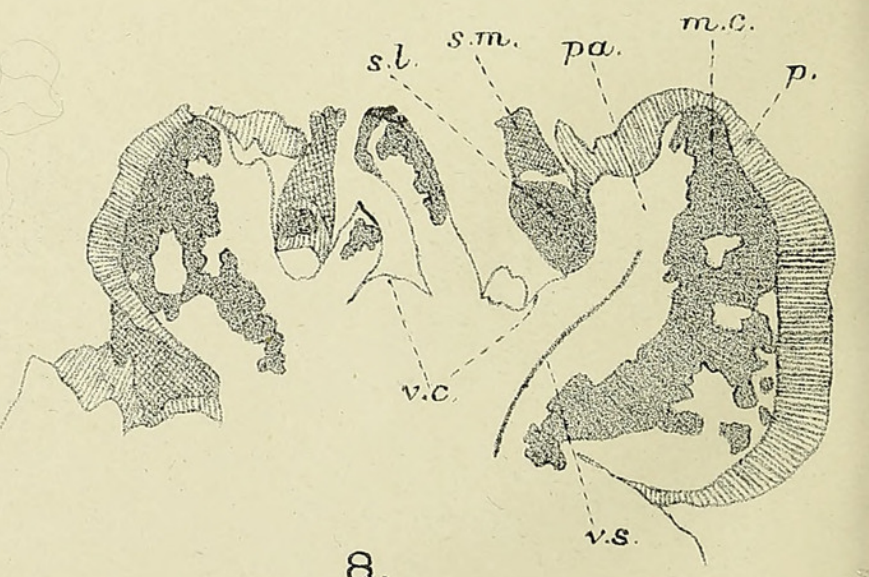


Annals of Botany,
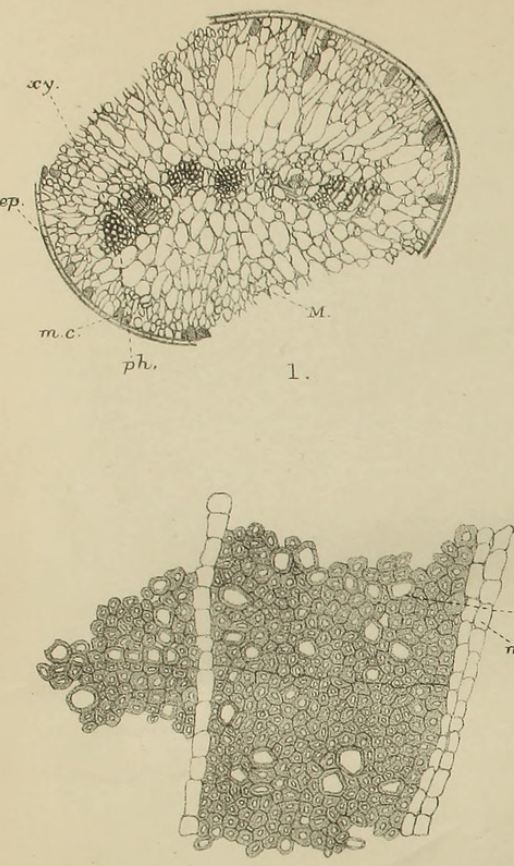

6.

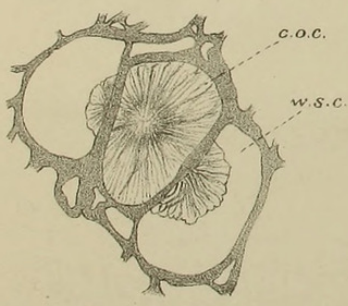

7.

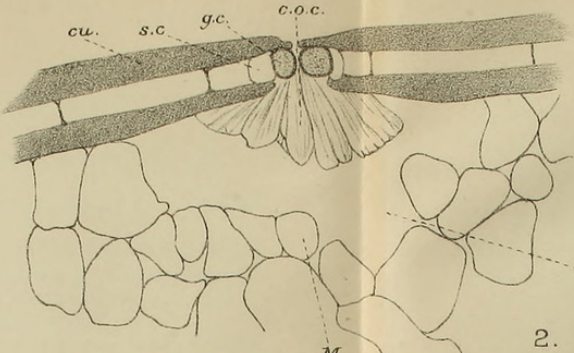

2.

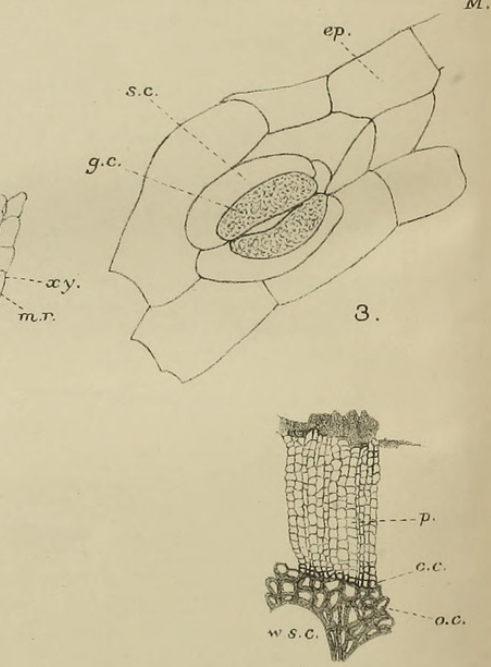

9.

s.m.

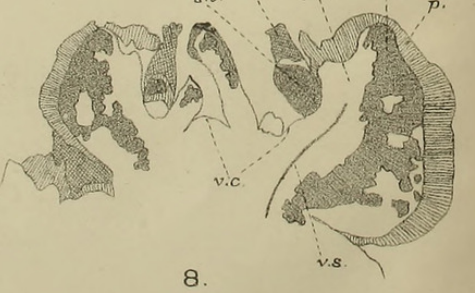

8

MICHELL - CERARIA AND PORTULACARIA
Vol. XXVI, Pl.XCVIII.

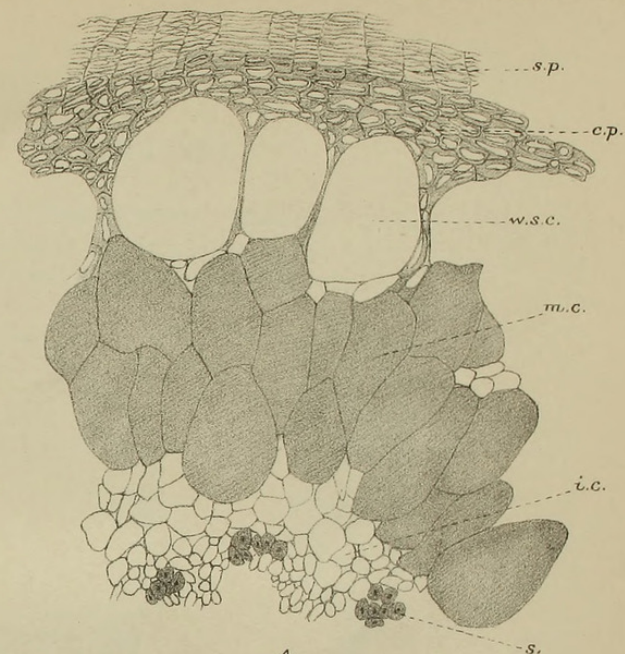

4.

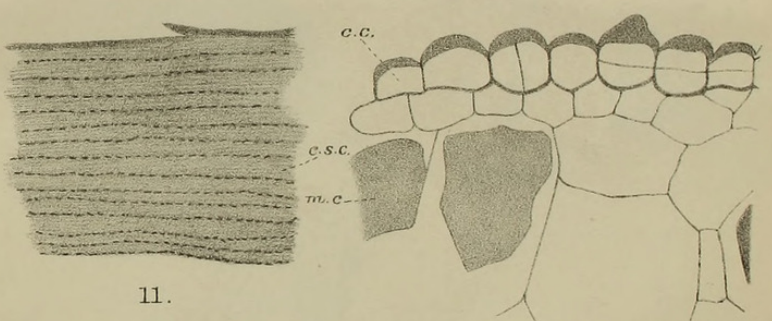

12.

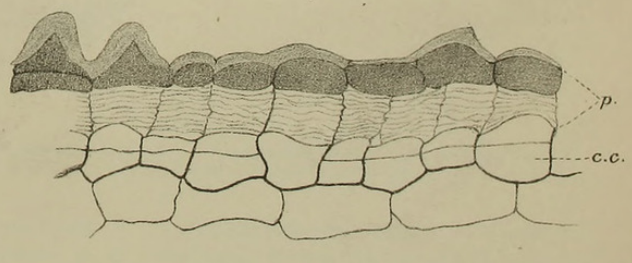

13. 


\section{$2 \mathrm{BHL}$ Biodiversity Heritage Library}

Michell, Margaret Rutherford. 1912. "On the comparative anatomy of the genera Ceraria and Portulacaria." Annals of botany 26, 1111-1122. https://doi.org/10.1093/oxfordjournals.aob.a089434.

View This Item Online: https://www.biodiversitylibrary.org/item/236930

DOI: https://doi.org/10.1093/oxfordjournals.aob.a089434

Permalink: https://www.biodiversitylibrary.org/partpdf/319950

\section{Holding Institution}

Smithsonian Libraries

\section{Sponsored by}

Biodiversity Heritage Library

\section{Copyright \& Reuse}

Copyright Status: Not in copyright. The BHL knows of no copyright restrictions on this item.

This document was created from content at the Biodiversity Heritage Library, the world's largest open access digital library for biodiversity literature and archives. Visit BHL at https://www.biodiversitylibrary.org. 